\title{
Development, Implementation and Evaluation of E-Learning Materials for FFL with Adobe Captivate Software
}

\author{
Sercan Alabay ${ }^{1} \&$ Mehmet Baştürk ${ }^{2}$ \\ ${ }^{1}$ School of Foreign Languages, Galatasaray University, Istanbul, Turkey \\ ${ }^{2}$ Necatibey Faculty of Education, Balıkesir University, Balıkesir, Turkey \\ Correspondence: Sercan Alabay, School of Foreign Languages, Galatasaray University, Ortaköy Çırağan Street, \\ 36, 34349 Istanbul, Turkey. E-mail: Sercan.alabay@gmail.com
}

Received: February 14, 2021

doi:10.5539/ies.v14n6p59

\author{
Accepted: March 15, 2021 \\ Online Published: May 14, 2021 \\ URL: https://doi.org/10.5539/ies.v14n6p59
}

\begin{abstract}
Developing technology has significantly affected the education and training process as it is in all areas of life. In today's society, smart phones, tablets and computers which almost every individual owns have facilitated access to information, and besides classical teaching methods, technology-supported or technology-based education activities have also become a part of the process. E-learning tools are important tools by which technology is included in the education and training process. Especially during the COVID-19 pandemic which has been experienced around the world since the beginning of 2020 has revealed the importance of e-learning materials more. The aim of this study, carried out in the light of the information given above, is to develop, apply and evaluate Adobe Captivate, one of the most used e-learning software worldwide, for use in the French teaching process. The study was carried out in an experimental model. The universe of the study consisted of 53 French preparatory class students. The achievement test developed by the researcher was used as the data collection tool of the research. The data obtained as a result of the pre-test and post-test applications showed that the use of Adobe Captivate positively affected the general language competency of the students.
\end{abstract}

Keywords: e-learning, French language teaching, Adobe Captivate, covid-19

\section{Introduction}

In line with changes and improvements in technology, the profile of students in today's schools has been changed. As the amount of information to which they are exposed has increased, students need new and contemporary methods of organizing their own learning, and these methods should be adapted to current and future needs. All these facts allow the education system to improve and adapt to the new era. Thus, traditional methods of teaching and learning should be changed to meet the needs of this era, resulting in the use of technology in education. The technology can be used for learning environments, for teaching materials and for methods for educational purposes.

Among all other topics, the use of technology, especially in language teaching, has been a common topic for scholars in recent years. Cell phones, tablets and personal computers are used in today's language learning environments. Mayer (2002) proposed one of the main theories related to language learning, namely multimedia learning theory. According to this theory, students learn best when information is presented with pictures and words, rather than words alone. This theory suggests that the multimedia learning process is an information acquisition process or a knowledge construction process. On the basis of these two theories, Mayer (2002) built his theory on nine principles which are the multimedia principle, the principle of spatial contiguity, the principle of temporal contiguity, the principle of coherence, the principle of modality, the principle of redundancy, the principle of pre-learning, the principle of signaling and the principle of personalization. Mayer (2002) pointed out that students learn best when words and pictures are presented simultaneously, because a learner needs to keep mental representations of words and pictures in working memory and can thus establish a connection between them.

Mayer (2002) multimedia learning theory has given rise to more contemporary theories such as online learning theory. Online learning theory can be defined as the effective learning process created by combining digitally delivered content with (learning) support and services (Mason \& Rennie, 2006). Mason and Rennie (2006) have stated that the need to update knowledge and skills, the need for retraining because lifelong jobs have all but 
disappeared, and the need to keep up with the explosion of Information on the Internet caused the birth of the theory of online learning (e-learning).

As seen above, online learning has significant and effective benefits. Thus, many software has been developed. Adobe Captivate is one of the most common and efficient. Bruyndonckx (2015) pointed out one should never forget that Captivate is an online learning creation tool if $\mathrm{s} / \mathrm{he}$ is working with it. It just means that the developer of the project is the teacher and the audience is the students. Thus, two sides of this online learning process are united by a very special kind of relationship: a student-teacher relationship.

Siegel (2015) reported that by using Adobe Captivate, a teacher can create e-learning courses on a wide list of concepts. If he/she needs to create an online lesson on terrorism awareness, or if he/she wants to prepare a course on conflict resolution, they can use Captivate to create e-learning content for everyone and for these elements. Siegel (2015) also claimed that the e-learning content a teacher can create with Captivate can be interactive: text, hotspots, quizzes, input boxes, sound effects, videos, special effects, audio, slides, etc. can be included in any e-learning content prepared by Adobe Captivate. In addition, projects prepared with Adobe Captivate can be published in Flash (SWF), HTML5, Word documents, PDFs and videos. Ultimately, they can be viewed by a consumer through a Macintosh or Windows PC or through a corporate web server, YouTube, Vimeo, mobile device such as iPad, iPhone, and Android, and even Adobe Reader if they are published in PDF format.

Bruyndonckx (2015) pointed out that Captivate has always been the leading solution for creating e-learning content since its introduction in 2004. The latest version of the program is 2019 and can perform including but not limited to followings:

- Software simulation

- Video demonstration

- Virtual Reality Experience Learning

- Interactive Videos

- PowerPoint to Responsive eLearning with Ease

- Interactive quizzes.

\subsection{The Development and Evaluation of Online Quizzes}

Adobe Captivate provides two types of checks: question slides, which are quiz-like assessment checks, and knowledge checks that are more of surveys.

- The knowledge check slide offers similar functionality to the question slide without any results, report structure, and interaction IDs.

- Knowledge check slides do not participate in reviews.

- Random questions are not applicable on this knowledge check slide.

- The main slide and the use of controls are similar to the question slide.

- Knowledge check slides can be used to convey learning on specific topics

On the other hand, question slides offer different types of questions:

- Multiple choice

- True/false

- Field to be completed

- Short answer

- Association

- Sensitive area

- Sequence

- Random question

In this study, an online placement test is created. In order to do this, the new project and the responsive project are clicked gradually. Then, a question slide from the slides menu is added. 


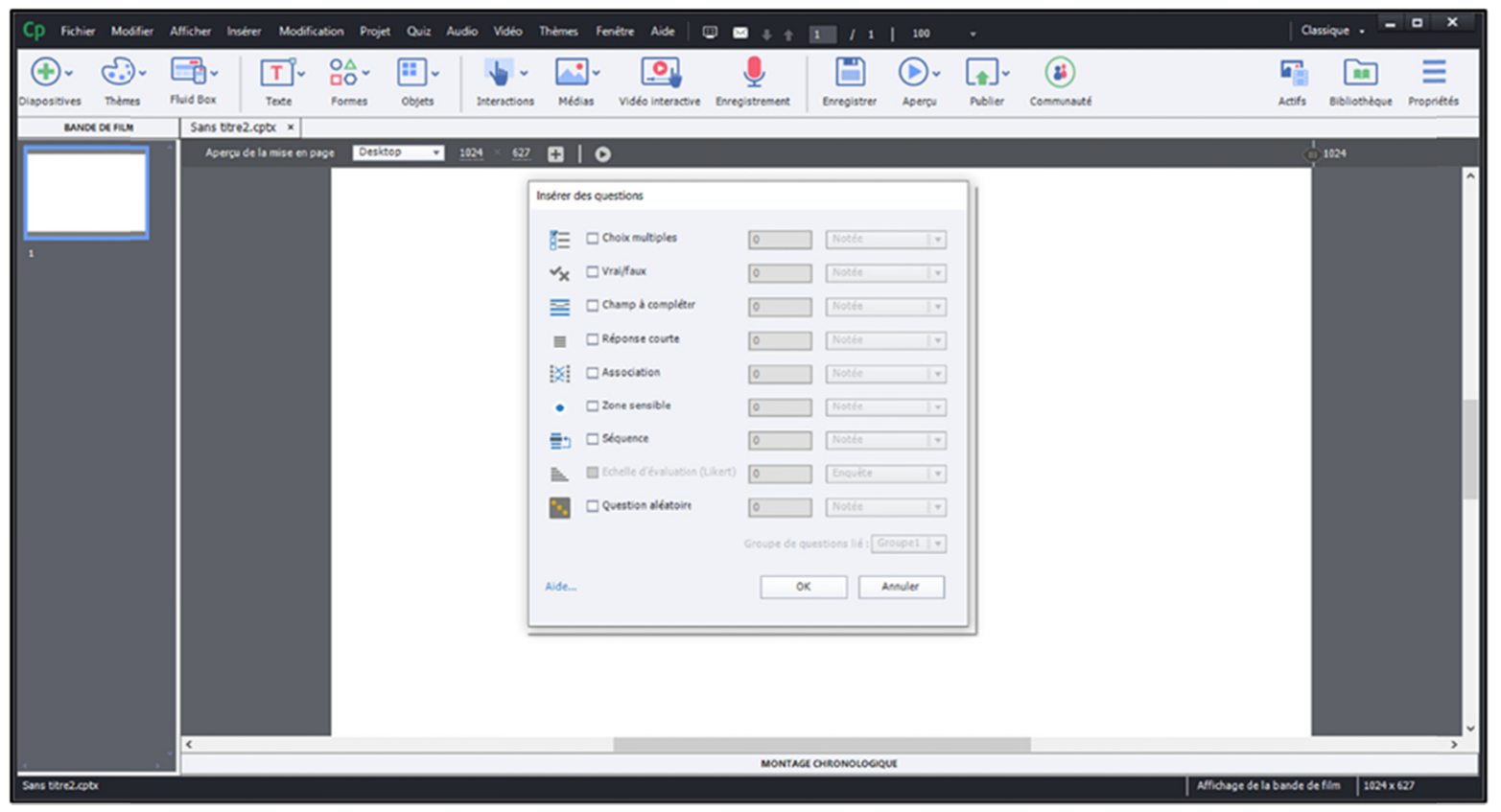

Figure 1. The different types of questions Adobe Captivate can create

The master slide and the results slide are created automatically. If the name of the student taking the exam wants to be displayed, the variable " $\$$ cpQuizStudentName $\$$ " is used by assigning it to a text box. A text caption can also be added to give information about the quiz. To be able to bring the learner's name up to the results slide, another text caption that contains the label of the variable should be added.

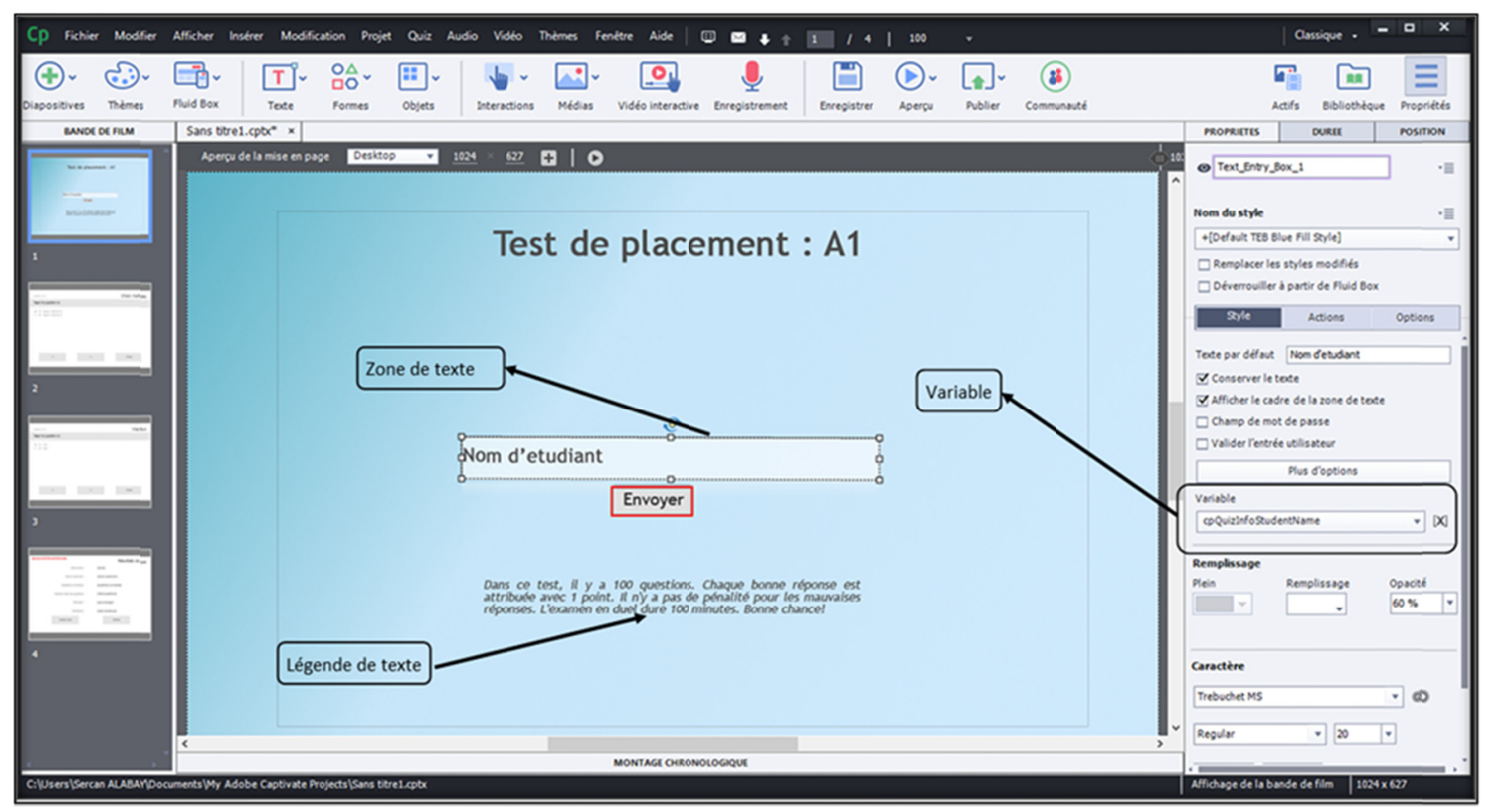

Figure 2. The preparation of a quiz

One of the 8 types of questions can be chosen and the slide can be added to the project. In the upper right corner of the software, there is the general quiz controls and slide specific point entry box. It is also possible to set a penalty for a false answer. The teacher can assign different points and penalties to the questions. The calculation will be done automatically and the results will be displayed on the last page of the quiz devoted to the scores. 
Each question slide has properties such as fill colors, alignment and margins, which are editable as required by the exam. It is possible to add question slides by right clicking on the left column of the software. The exam designer can also add all question slides from the main screen by entering the quantity for each question type.

The project can be previewed at each stage or at the end by clicking on the "Preview" button in the top menu of the software. Live preview on peripherals allows us to preview the project in real time on tablets or smartphones. Another option is "Preview Project" which demonstrates it on the computer browser. It is also possible to preview it on the SCORM cloud if we have access to it.

For quizzes that contain multiple questions, adding a table of contents makes it easier for the user to navigate. To do this, you must press Shift + F10 or click "table of contents" under the Project menu.

There are several publication choices once the quiz preparation is complete. Under the "Publish" menu the first option is to publish for devices as HTML5, which works on computers, and on IOS and Android mobile devices. Connect and Prime is paid services from Adobe and with registration, posting to these services is provided. Publish for devices (app) allow you to directly create native apps for IOS and Android through Phone Gap (another Adobe service).

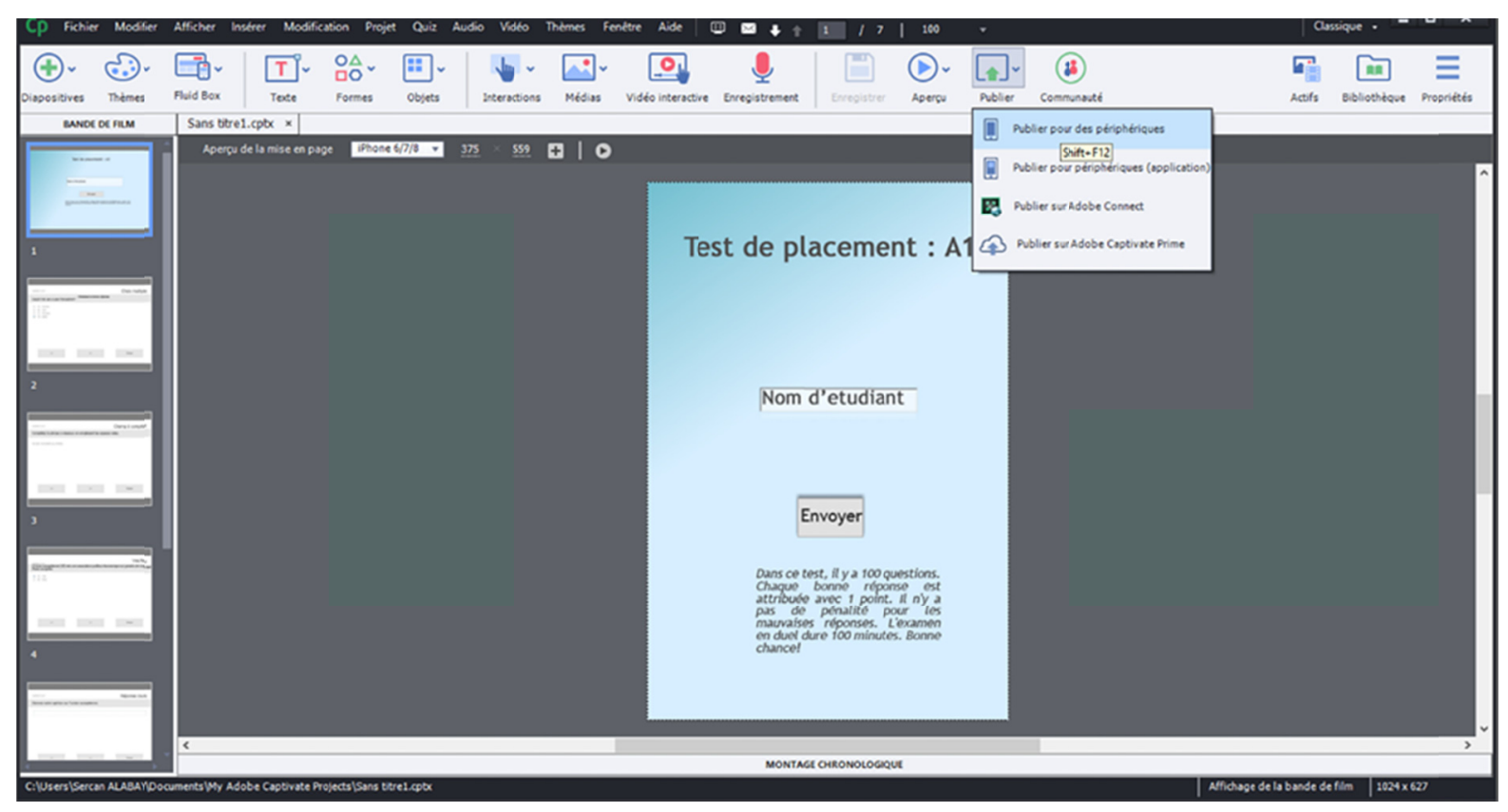

Figure 3. The publication choices

Publishing for SCORM is also useful if a Learning Management System (LMS) is used especially for quizzes. 


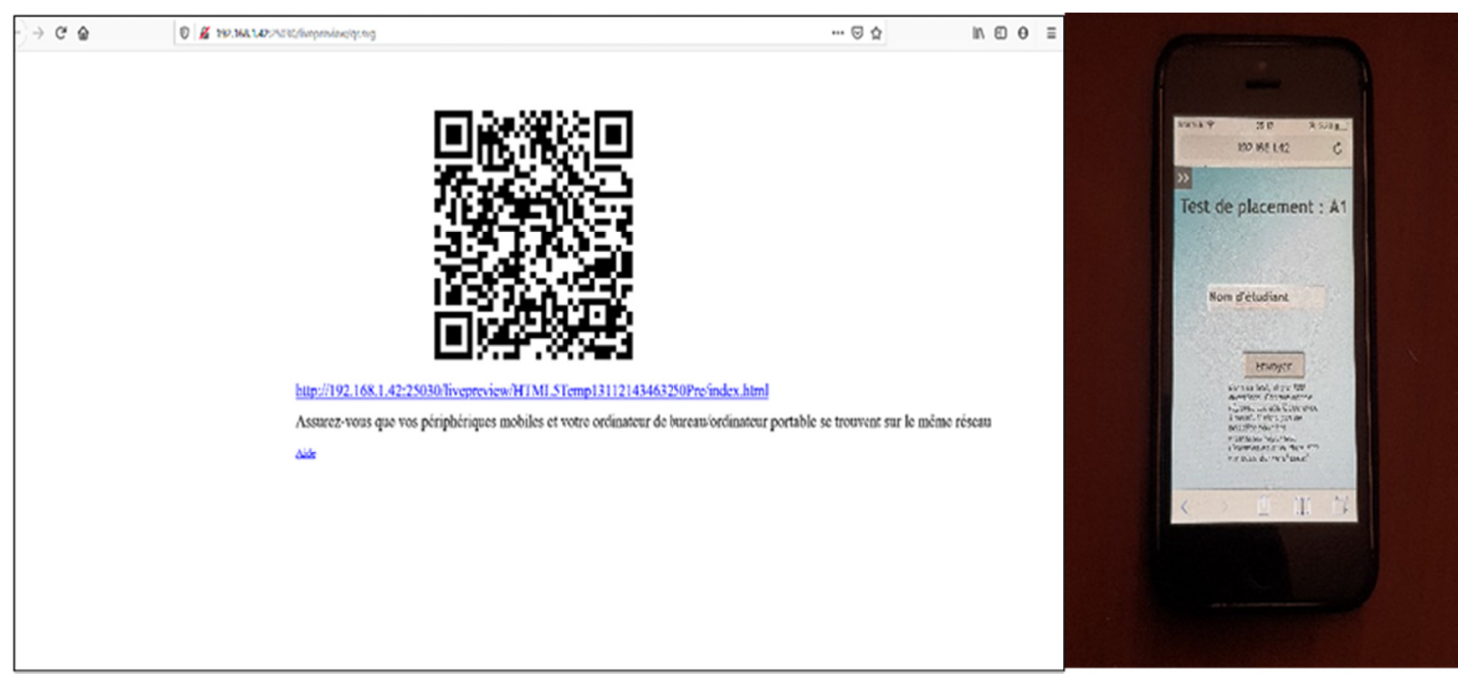

Figure 4. The barcode created by Captivate to access the project on a laptop

In the example of this study, when the quiz project was published, the barcode was automatically created by Adobe Captivate, and it was scanned by an Apple iPhone 5s. Thanks to the responsive project, not only on computers but also on mobiles the user experience was smooth.

\subsection{Video Demonstrations}

Adobe Captivate is capable of creating studio-quality video demos for use in distance education and in the classroom. Screen content can be captured with webcam audio, closed captions, or video.

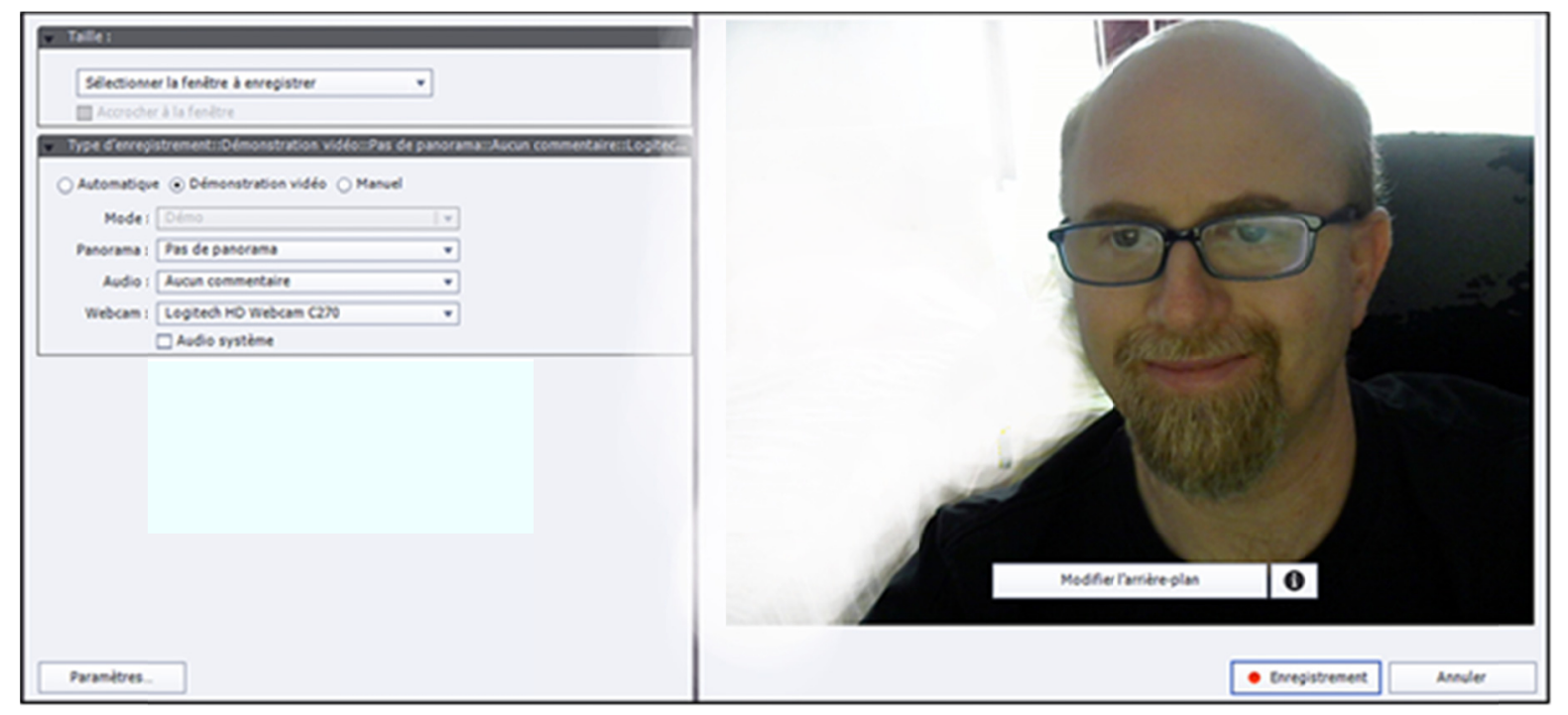

Figure 5. Preparing for a video demonstration

To start recording a video demonstration, the followings should be done:

- Click on Video demo on the welcome screen, or, click File> Record New> Video Demo.

- The recording area is marked with a red border, and the recording choices are presented.

- Click on Screen area or on the application depending on what you want to film

- Choose a panoramic mode if you want the recording area to accompany the activities on the screen.

- In case of narration during recording, choose the audio input type.

- It is possible to customize the backgrounds of the videos. 
- Press Save.

- $\quad$ Press the End button (under Windows) or Cmd + Enter (Mac OS) to finish.

Once the process is complete, the user has three options:

- $\quad$ Save video as MP4 file

- Share directly on YouTube, Twitter or Facebook

- Transform video in Adobe Captivate (elearninglearning.com, 2019)

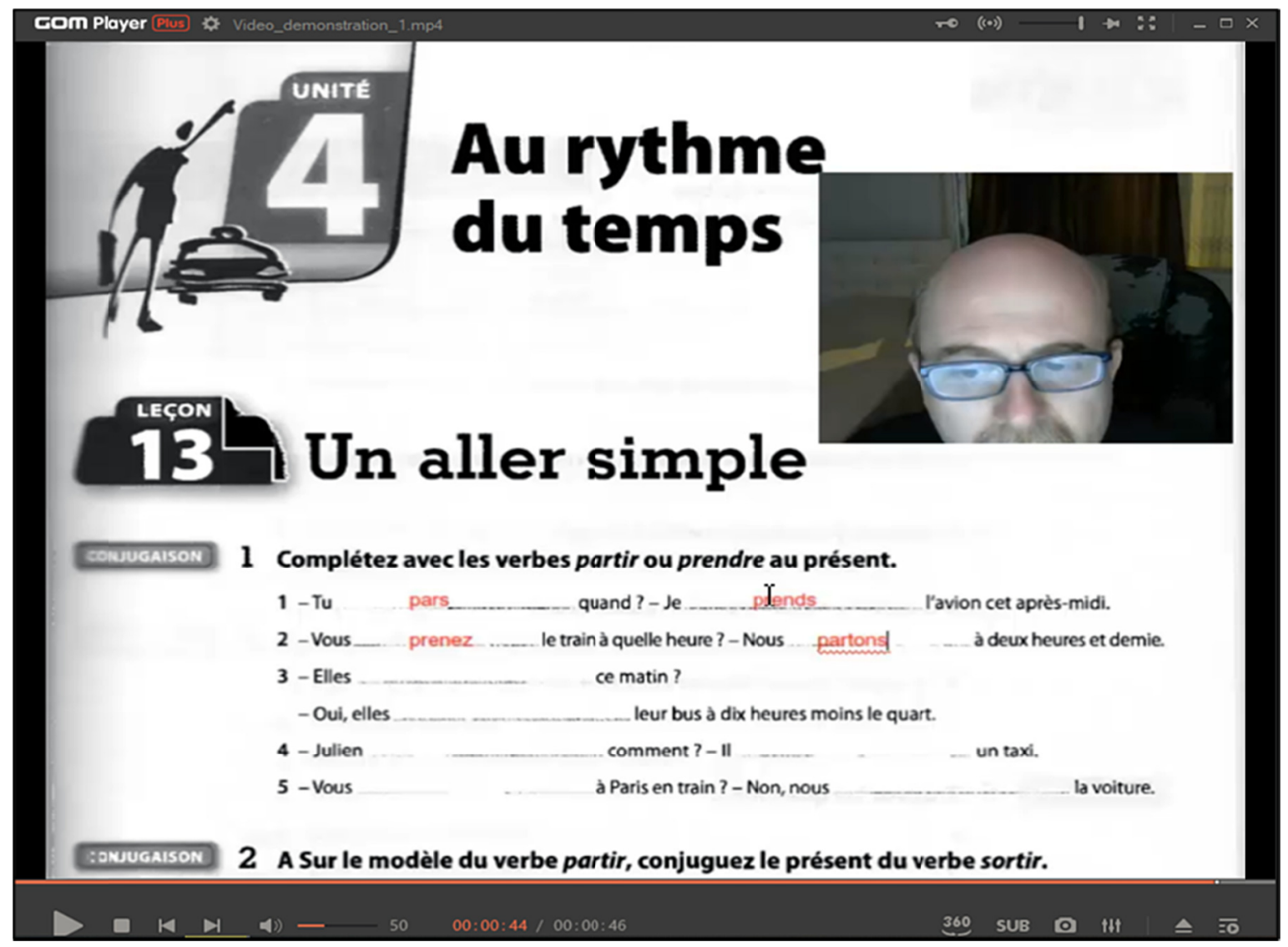

Figure 6. A recorded video demonstration

Within the light of the information presented above, this research aims to examine the effects of using Adobe Captivate on teaching French as a foreign language. There are some studies which discussed the use of Adobe Captivate on teaching English (Boukhechba \& Bouhania, 2019; Pulansari, 2014). However, there is a gap in the literature about using Adobe Captivate to teach French. Since it is very important and beneficial to use technology to teach a foreign language, the use of software and the analysis of its impact on this process has become a major area of research. By defining the effects, this study is supposed to fill the gap in the literature and to inform teachers and educational planners. The research questions are as follows:

1) How does Adobe Captivate affect student language learning?

2) Is there a significant difference between the control group and the experimental group in terms of reading, listening, grammar and lexical comprehension skills?

2a) Is there a significant difference between the control group and the experimental group in terms of reading skills?

2b) Is there a significant difference between the control group and the experimental group in terms of listening skills?

2c) Is there a significant difference between the control group and the experimental group in terms of grammatical 
competence?

2d) Is there a significant difference between the control group and the experimental group in terms of lexical competence?

\section{Method}

\subsection{Population}

The population of the study consists of French students in preparatory class at Bursa Uludağ University. Any type of sampling method was not used, since all of the students in the prepatory class were included. There are two classes which include 53 students. The number of female students is 41 out of 53 students $(77.36 \%)$, while the number of male students is $12(22.64 \%)$. The age range of students is $18(66.04 \%), 19(22.64 \%)$ and $20(11.32 \%)$. The level of linguistic competence of these students is the beginner level (100\%). The mother tongue of all students is Turkish. The demographic information of students is presented in Table 1.

Table 1. The demographic information of students

\begin{tabular}{lccc}
\hline Group & & $f$ & $\%$ \\
\hline \multirow{2}{*}{ Gender } & Female & 41 & 77.36 \\
& Male & 12 & 22.64 \\
\hline \multirow{3}{*}{ Age } & 18 & 35 & 66.04 \\
& 19 & 12 & 22.64 \\
Level of linguistic competence & 20 & 6 & 11.32 \\
The mother tongue & Beginner & 53 & 100 \\
\hline
\end{tabular}

One of these classes was assigned as a control group, which is coded as class B, and the other class was an experimental group, which is coded as class A. The experimental group was exposed to Adobe Captivate, the control group used only textbooks. The number of students in class A was around 25, and in class B was 28 . They share similar backgrounds.

\subsection{Research Design}

This research design was an experimental survey design, which is one of the survey models. Surveys, in general, aim to seek out an existing situation in its own existence. They try to define the situations or individuals that are sought in their own context, and it does not try to change or affect the variables. Creswell (2013) divided the survey designs into three groups, which are pre-experimental, experimental and semi-experimental research designs.

\subsection{Data Collection Tools}

\subsubsection{Adobe Captivate}

For this study, Adobe Captivate was designed by the researcher to be used in the course to supplement the French textbook used in the classes, which is titled "Le nouveau taxi 1". Adobe Captivate aims to support the skills of listening and reading, as well as grammar and vocabulary. For this purpose, the words, grammatical rules, and exercises that support reading and listening skills for the chosen unit have been determined and the appropriate exercises for them have been designed in Adobe Captivate. For example, the vocabulary elements were taught with their meanings and the images associated with them; grammar rules activities were interactive.

\subsubsection{The Achievement Test}

Achievement tests are useful instruments for measuring knowledge of language learning skills (Nation, 1990, 2001; Richards, 1976; Ringbom, 1987). In this study, the researcher developed an achievement test as a measuring instrument to be used in the analysis. It has nine questions under four sections; which are a vocabulary section, a grammar section, a reading section and a listening section.

\subsubsection{Data Collection Procedure}

During the data collection process, the achievement test which was prepared as explained below was implemented as both pretest and posttest. First, the pre-test was applied for all participating students $(n=53)$ one week before treatment, the pre-tests were supposed to give us the actual level of students before treatment in all groups. The study then included experimental and control groups. These groups were formed with the inclusion of two French preparatory classes at Bursa Uludağ University. While the experimental group was exposed to Adobe Captivate, 
the control group received course manuals. Second, after the treatment process finished, all groups received the same post-test. The post-test was believed to indicate progress with a one-month treatment.

\subsubsection{Data Analysis}

The quantitative data was analyzed during the research. The SPSS (Statistical Package for Social Sciences for Windows 25.0) was used for the analysis. Descriptive statistics (arithmetic mean, frequency, standard deviation) were performed. Normality tests were performed to decide whether the data was normally distributed or not. Since the number of students for the control group and the experimental group was less than 30, the Shapiro-Wilk normality test was used. The results for each question and research sub-question showed that the data was not normally distributed. Thus, the non-parametric tests were carried out. In order to test whether there was a significant difference between the two groups, the Mann Whitney U test was used.

\section{Results}

In order to understand the effect of Adobe Captivate on students' foreign language learning, descriptive statistics were used. The results are shown in Table 2.

\subsection{Research Question 1}

In order to understand the effect of Adobe Captivate on students' foreign language learning, descriptive statistics were used. The results are shown in Table 2.

Table 2. Descriptive statistics for the post-test results of the experimental group and the control group

\begin{tabular}{cccccc}
\hline Groups & $\mathrm{N}$ & Minimum & Maximum & $\bar{X}$ & $\mathrm{SD}$ \\
\hline Control & 28 & 25 & 65 & 42.11 & 11.38 \\
Experimental & 25 & 40 & 95 & 70.28 & 16.84 \\
\hline
\end{tabular}

The results of Table 2 show that the post-test score of the controlled group $(\bar{X}=42.11, \mathrm{SD}=11.38)$ is lower than the post-test score of the experimental group $(\bar{X}=70.28, \mathrm{SD}=16.84)$. The minimum score of the controlled group for the post-test is 25 , and the maximum score for the post-test is 65 . However, the minimum score of the experimental group for the post-test is 40 , while the maximum score is 95 .

\subsection{Research Question 2}

\subsubsection{Research Question 2a}

In order to test the impact of Adobe Captivate on the reading skills of FLE students, the Shapiro Wilk normality test was first applied to the post-test. The reason for using Shapiro Wilk is that the number of students was less than 30. The results are shown in Table 3.

Table 3. The results of the tests of normality of the results of the post-test for the reading skills of the two groups

\begin{tabular}{ccc}
\hline & $\begin{array}{c}\text { Posttest results } \\
\text { Control group }\end{array}$ & $\begin{array}{c}\text { Posttest results } \\
\text { Experimental group }\end{array}$ \\
\hline N & 28 & 25 \\
Shapiro-wilk & 0.010 & 0.052 \\
$P$ & 0.010 & 0.023 \\
\hline
\end{tabular}

The results of the normality tests show that the scores of FLE students on the reading tests do not show a normal distribution ( $p=0.01<0.05 ; p=0.023<0.05$ ). Thus, the nonparametric test, Mann Whitney $U$, was used.

In order to understand if there was a significant difference between the post-test results of the reading comprehension tests of the control group and the experimental group, the Mann Whitney U test was applied and the results are presented below (Table 4).

Table 4. Mann Whitney U test results for reading comprehension scores of students

\begin{tabular}{ccccccc}
\hline Groups & & $\mathrm{N}$ & $\bar{X}$ & Standard deviation & $\mathrm{U}$ & $\mathrm{P}$ \\
\hline \multirow{2}{*}{ Reading scores } & Control & 28 & 41.85 & 15.98 & \multirow{2}{*}{3.284} & \multirow{2}{*}{0.000} \\
& Experimental & 25 & 68.20 & 11.91 & & \\
\hline
\end{tabular}


The results presented in Table 4 show that there is a significant difference between the controlled group $(\bar{X}=$ $41.85)$ and the experimental group $(\bar{X}=68.20)$ the post-test results of the reading tests $(\mathrm{U}=3.284, \mathrm{p}=0.000<$ $0.05)$.

\subsubsection{Research Question 2b}

In order to test the impact of Adobe Captivate on the listening skills of FLE students, Shapiro Wilk's normality test was first applied to the post-test (Table 5).

Table 5. The results of the normality tests of the scores of the listening

\begin{tabular}{ccc}
\hline & $\begin{array}{c}\text { Posttest results } \\
\text { Control group }\end{array}$ & $\begin{array}{c}\text { Posttest results } \\
\text { Experimental group }\end{array}$ \\
\hline N & 28 & 25 \\
Shapiro-Wilk & 0.122 & 0.325 \\
$P$ & 0.017 & 0.028 \\
\hline
\end{tabular}

The results of the normality tests show that the post-test scores of FLE students on the listening comprehension tests do not show a normal distribution $(\mathrm{p}=0.017<0.05 ; \mathrm{p}=0.028<0.05)$. Thus, the nonparametric test, Mann Whitney $\mathrm{U}$, was used.

In order to understand if there was a significant difference between the post-test results of the listening tests of the controlled group and of the experimental group, the Mann Whitney U test was applied and the results are presented below (Table 6).

Table 6. Results of the Mann Whitney U test for listening skills

\begin{tabular}{ccccccc}
\hline Groups & & $\mathrm{N}$ & $\bar{X}$ & Standard deviation & $\mathrm{U}$ & $\mathrm{P}$ \\
\hline \multirow{2}{*}{ Listening comprehension scores } & Control & 28 & 58.30 & 4.79 & \multirow{2}{*}{6.345} & \multirow{2}{*}{0.000} \\
& Experimental & 25 & 81.75 & 10.82 & & \\
\hline
\end{tabular}

The results of the Mann Whitney $\mathrm{U}$ test show that there is a significant difference between the control group $(\bar{X}=$ $58.30)$ and the experimental group $(\bar{X}=81.75)$ the post-test results of the listening tests $(U=6.345, p=0.000<$ $0.05)$

\subsubsection{Research Question 2c}

To test the impact of Adobe Captivate on the grammatical competence of FLE students, the Shapiro Wilk normality test was applied to the post-test first (Table 7).

Table 7. The results of normality tests of grammatical competence

\begin{tabular}{ccc}
\hline & $\begin{array}{c}\text { Posttest results } \\
\text { Control group }\end{array}$ & $\begin{array}{c}\text { Posttest results } \\
\text { Experimental group }\end{array}$ \\
\hline N & 28 & 25 \\
Shapiro-Wilk & 0.209 & 0.125 \\
P & 0.032 & 0.015 \\
\hline
\end{tabular}

Normality test results indicate that the grammar test scores of FLE students do not show a normal distribution $(\mathrm{p}=$ $0.032<0.05 ; \mathrm{p}=0.015<0.05)$. Thus, the nonparametric test, Mann Whitney $\mathrm{U}$, was used.

In order to understand if there was a significant difference between the post-test results of the control and the grammar tests of the experimental group, the Mann Whitney U test was applied and the results are shown in Table 8. 
Table 8. Mann Whitney U test results for students' grammar scores

\begin{tabular}{ccccccc}
\hline Groups & & $\mathrm{N}$ & $\bar{X}$ & Std. Deviation & $\mathrm{U}$ & $\mathrm{P}$ \\
\hline \multirow{2}{*}{ Grammar scores } & Control & 28 & 31.75 & 14.87 & \multirow{2}{*}{9.396} & \multirow{2}{*}{0.000} \\
& Experimental & 25 & 78.10 & 10.80 & & \\
\hline
\end{tabular}

The results of the Mann Whitney $\mathrm{U}$ test presented in Table 8 show that there is a significant difference between the control group $(\bar{X}=31.75)$ and the experimental group $(\bar{X}=78.10)$ the post-test results of the grammar tests $(\mathrm{U}=$ $9.396, \mathrm{p}=0.000<0.05)$.

\subsubsection{Research Question 2d}

To test the impact of Adobe Captivate on the lexical competence of FLE students, Shapiro Wilk's normality test was first applied to the post-test (Table 9).

Table 9. The results of the tests of normality of the scores of the lexical competence

\begin{tabular}{ccc}
\hline & $\begin{array}{c}\text { Posttest results } \\
\text { Control group }\end{array}$ & $\begin{array}{c}\text { Posttest results } \\
\text { Experimental group }\end{array}$ \\
\hline N & 28 & 25 \\
Shapiro-Wilk & 0.406 & 0.215 \\
$P$ & 0.026 & 0.038 \\
\hline
\end{tabular}

The results of the normality tests show that the scores of the FLE students on the lexical competence do not show a normal distribution $(p=0.026<0.05 ; p=0.038<0.05)$. Thus, the Mann Whitney $U$ test was used.

In order to understand if there was a significant difference between the post-test results of the vocabulary tests of the controlled group and of the experimental group, the Mann Whitney U test was applied and the results are presented below (Table 10).

Table 10. Mann Whitney U test results for students' lexical competence

\begin{tabular}{ccccccc}
\hline Groups & & $\mathrm{N}$ & $\bar{X}$ & Std. Deviation & $\mathrm{U}$ & $\mathrm{P}$ \\
\hline \multirow{2}{*}{ Scores of vocabulary } & Control & 28 & 62.05 & 12.36 & \multirow{2}{*}{7.369} & \multirow{2}{*}{0.000} \\
& Experimental & 25 & 84.23 & 11.71 & & \\
\hline
\end{tabular}

The results of the Mann Whitney $\mathrm{U}$ test show that there is a significant difference between the control group $(\bar{X}=$ $62.05)$ and the experimental group $(\bar{X}=84.23)$ The post-vocabulary test results are $(U=7.369, p=0.000<0.05)$.

\section{Discussion}

In 2020, the need for e-learning has increased dramatically as COVID-19 has resulted in the closure of schools all over the world. Globally, more than 1.2 billion children are out of the classroom. As a result, education has changed dramatically, with the particular rise of online learning, in which education is delivered at a distance and on digital platforms. Research suggests that online learning has been shown to increase information retention and take less time, which means that changes caused by the coronavirus could be long-lasting. Adobe Captivate is one of the e-learning tools which can be benefited from for e-learning. Some research has been done on using Adobe Captivate for distance education in Turkey (Kaya, 2012) and other countries (Crampton, Ragusa, \& Cavanagh, 2012), in the teaching of statistics (Poláčková \& Jindrová, 2010) and in the teaching of mechatronics (Y1lmaz \& Tunçalp, 2010). When it comes to French language teaching, it's almost impossible to find any research on direct use of Adobe Captivate. Thus, this study aims to examine the effects of using Adobe Captivate on FLE.

For the first research questions, it was seen that the students who used Adobe Captivate performed better on the achievement test, and the difference between the control and experimental group was significant. The reason why the experimental group was more successful could be explained by the use of additional and interactive material while doing exercises. The immediate feedback provided by Adobe Captivate could lead students to correct their mistakes and learn from them. The results show similarities with other studies in the literature. For example, Dewanti and Rusli (2019) conducted a study on using Adobe Captivate to design e-learning content for a tourism-related course. They pointed out that using Adobe Captivate for this course created opportunities to 
benefit from different media and made the interactive learning environment that motivated learners and maximized learning potential. While this study is not directly related to language learning, it does confirm that using Adobe Captivate is beneficial for online learning environments. Contrary to the research explained above, Sun (2011) conducted a study on the use of virtual classrooms to teach Chinese to New Zealand students and found that it was not effective. Sun (2011) explained that there are many educational challenges when conducting the e-learning process.

The second research question was to determine whether there was a significant difference between the listening and reading skills of two groups and their learning of grammar and vocabulary. First, the students' reading comprehension skills were analyzed and compared. The results showed that the experimental group obtained higher scores than the control group and this difference was significant. Reading activities on textbooks can sometimes be boring for students as they just read them and answer questions. However, a reading text and its activities prepared in Adobe Captivate are more interactive. Students can look up unfamiliar words in the online dictionary more easily as they work on a computer. In addition, they can get tips for answering comprehension questions when they are having difficulty. Plus, they can get immediate feedback. All of these facts can positively affect reading skills. The idea of the positive impact of the use of software on reading has been supported by other research in the literature. In their study, Smith and Wang (2013) carried out a project in which Japanese students were engaged in learning English through an interface of their mobile phone. Smith and Wang (2013) regularly sent reading materials and activities to students' cell phones. When choosing materials, certain criteria were determined by the researchers. These criteria included choosing reading materials that were neither too long nor too demanding, monitoring teachers, and involving students in activities by choosing texts that would grab their attention, and presenting a secure mobile learning environment. Smith and Wang (2013) mentioned that texts are sometimes written by one student are read by another and they find them really interesting and authentic. They found it increased their motivation to read. Smith and Wang (2013) also found that reading texts related to cultural differences, English jokes and puzzles, and English proverbs/quotes are the most popular ones with students.

The second sub-question of the second research question was whether there was a significant difference between the listening skills of the two groups. It was found that the post-test results of the students in the experimental group were higher than those in the control group. Perdana and Muhammady (2019) conducted research on teaching listening skills in a blended learning environment (a learning environment that includes both online and face-to-face learning processes). The results showed that blended learning has certain advantages, which are easy to implement and flexible, allowing students to study their listening skills at their own pace.

The third sub-question of the second research question was whether there was a significant difference between the grammatical competence of the two groups. The results showed that the experimental group obtained very high scores in post-test compared to the control group, and the difference between the scores of the two groups was significant. Grammar has always been a problematic area for the language learning process, and many studies have been carried out on how to improve it. Some research has similar results with this research and suggests that the use of technology can be very helpful. For example, Barr (2008) carried out a project in which French grammar was taught in multimedia learning laboratories. Before the implementation, $60 \%$ of students was found learning grammar unpleasant. After benefiting from the online learning management system to study grammar, students scored higher on 13 out of 16 questions compared to the first test which was taken before the grammar learning process in line.

The final sub-question was about the impact of Adobe Captivate on students' lexical competence. The results showed that the experimental group obtained higher scores than the control group although the pre-test results of the control group were higher. The results of the Mann Whitney $U$ test showed that the difference between the two groups was significant. Like other findings, this one is also consistent with findings from other researches. For example, Al-Jarf (2007) conducted a study in which vocabulary was taught to 53 EFL students online. An online software called Nicenet was used. Along with classroom instruction, students received additional resources each week through this software and these resources included explanations, exercises and quizzes related to the topic of this course.

All of the findings and the discussion above show that using e-learning tools is an inevitable fact from which all language teachers should benefit. Designing courses and classroom activities accordingly with e-learning would contribute to the effective language learning process, especially during pandemics. Thus, policy-makers and authorities should seriously think about changing the traditional language teaching methods with the contemporary ones and plan courses and curriculums depending on this.

As any other research, this one has limitations. Firstly, this study is conducted in just one public university. 
Conducting in any other universities in Turkey, and all around the world, would give opportunity to see the big picture. Also, this study is a quantitative study. If the aim would be having a deeper understanding, a qualitative study should be conducted and the reasons behind students' success for language learning with Adobe Captivate could be understood better.

\section{References}

Al-Jarf, R. (2007). Teaching vocabulary to EFL college students online. Call-EJ Online, 8(2), 8-2.

Barr, D. (2008). Computer-enhanced grammar teaching. In Handbook of research on computer-enhanced language acquisition and learning (pp. 101-114). IGI Global. https://doi.org/10.4018/978-1-59904-895-6.ch007

Boukhechba, H., \& Bouhania, B. (2019). Adaptation of Instructional Design to Promote Learning in Traditional EFL Classrooms: Adobe Captivate for E-Learning Content. International Journal of Education and Development using Information and Communication Technology, 15(4), 151-164.

Bruyndonckx, D. (2015). Mastering Adobe Captivate 8. Birmingham: Packt Publishing Ltd.

Crampton, A., Ragusa, A. T., \& Cavanagh, H. (2012). Cross-discipline investigation of the relationship between academic performance and online resource access by distance education students. Research in Learning Technology, 20(1). https://doi.org/10.3402/rlt.v20i0.14430

Creswell, J. W. (2013). Steps in Conducting a Scholarly Mixed Methods Study. DBER Speaker Series. Paper 48

Kaya, M. (2012). Distance education systems used in universities of Turkey and Northern Cyprus. Procedia-Social and Behavioral Sciences, 31, 676-680. https://doi.org/10.1016/j.sbspro.2011.12.123

Mason, R., \& Rennie, F. (2006). Elearning: The key concepts. New York: Routledge. https://doi.org/10.4324/9780203099483

Mayer, R. E. (2002). Multimedia learning. Psychology of learning and motivation, 41, 85-139. https://doi.org/10.1016/S0079-7421(02)80005-6

Perdana, W. K. P., \& Muhammady, G. P. (2019). Designing blended learning course for teaching listening and speaking skills: Teachers and students' perspective. In The 7th Undergraduate Conference on ELT, Linguistic and Literature (2019) (p. 40).

Poláčková, J., \& Jindrová, A. (2010). Innovative approach to education and teaching of statistics. Journal on Efficiency and Responsibility in Education and Science, 3(1), 14-27.

Pulansari, H. (2014). Developing English Vocabulary Material Using Adobe Captivate Application for Young Learners (Doctoral dissertation, Universitas Muhammadiyah Gresik).

Siegel, D. (2015). E-Learning Methods to Teach Clinical Documentation Improvement. Minnesota: The College of St. Scholastica.

Smith, S., \& Wang, S. (2013). Reading and grammar learning through mobile phones. Language Learning \& Technology, 17(3), 117-134.

Sun, S. Y. H. (2011). Online language teaching: The pedagogical challenges. Knowledge Management \& E-Learning: An International Journal, 3(3), 428-447. https://doi.org/10.34105/j.kmel.2011.03.030

Supuwiningsih, N. N., Dewanti, P., \& Rusli, M. (2019, August). The Effect of E-Learning on Students Learning of STMIK STIKOM Bali. In 2019 1st International Conference on Cybernetics and Intelligent System (ICORIS) (Vol. 1, pp. 200-205). IEEE. https://doi.org/10.1109/ICORIS.2019.8874872

Yilmaz, Ö., \& Tunçalp, K. (2010). A mixed learning approach in mechatronics education. IEEE Transactions on Education, 54(2), 294-301. https://doi.org/10.1109/TE.2010.2053932

\section{Copyrights}

Copyright for this article is retained by the author(s), with first publication rights granted to the journal.

This is an open-access article distributed under the terms and conditions of the Creative Commons Attribution license (http://creativecommons.org/licenses/by/4.0/). 